Annals of Warsaw University of Life Sciences - SGGW

Land Reclamation No 49 (4), 2017: 269-276

(Ann. Warsaw Univ. of Life Sci. - SGGW, Land Reclam. 49 (4), 2017)

\title{
The changes of surface and ground water level on the effect of regulated outflow
}

\author{
ANTONI GRZYWNA, ALINA KOWALCZYK-JUŚKO, \\ KRZYSZTOF JÓŹWIAKOWSKI \\ Faculty of Production Engineering, University of Life Sciences in Lublin
}

\begin{abstract}
The changes of surface and ground water level on the effect of regulated outflow. This paper aims to analyze the variability of the levels of surface and ground water in the Ochożanka ba$\sin$. The depth at which the ground water table occurred was studied with reference to the adopted land drainage standards. The studies were carried out in 2009/2010-2014/2015 for natural and regulated water outflows. The analysis of annual total precipitation in the analyzed period some years were very wet (2009/2010 and 2013/2014), some of them were wet $(2010 / 2011,2012 / 2013)$, one year was dry $(2014 / 2015)$ and one year was normal (2011/2012). The six-year average seasonal precipitation amounted to $593 \mathrm{~mm}$, which was $66 \mathrm{~mm}$ higher than average precipitation recorded in 30 years. Under regulated outflow conditions the level of water in the river ranged from 55 to $77 \mathrm{~cm}$. The level of water under natural outflow ranged from 18 to $49 \mathrm{~cm}$. In the area with regulated outflow the average ground water level was $47 \mathrm{~cm}$. In the remaining area of drainage system ground water level was $67 \mathrm{~cm}$. Also, the dynamics of variance in the water level under natural outflow conditions was clearly higher.
\end{abstract}

Key words: adjustable outflow, precipitation, surface water, ground water

\section{INTRODUCTION}

Water protection is comprehensively regulated by the Water Framework Direc- tive the main goal of which is ensuring good quality of water. In Poland, water protection takes on a special significance because it is very poor water resources (Zieliński and Słota 1996). Water deficit imposes limitations on the possibility of economic development and necessitates a thorough analysis of risks (Mioduszewski 1999). Polesie Lubelskie is an area with first class water retention storage needs. Availability of water in the specific amount, quality and quantity is an essential element of sustainable development (Michalczyk 2000).

Water and natural factors determine the environment. In addition, certain adverse effects connected with water occur - droughts and floods. Apart from spatial variation in the distribution of precipitation, with its variability in years and seasons (Michalczyk and Wilgat 1999, Bajkiewicz-Grabowska and Mikulski 2006). The identification of the ecological status of surface water should involve a description of changes in the outflow regime (Brandyk 2002). Such changes are measured as the ratio of average regulated and natural outflow. Information about water resources includes characteristic water levels and outflows in months. 
As a result of the deteriorated technical condition of drainage systems, subsidence and poor maintenance, some systems have ceased to perform their functions (Bykowski et al. 2011). Most subsoil irrigation systems must now be modernized in order to reduce their decapitalisation and restore their original function. Proper use of peat-muck soils and rational water management must be ensured (Brandyk et al. 2008, Oleszczuk et al. 2009, Oleszczuk et al. 2012). Proper water management provides protection against degradation of soils and their agricultural use can be ensured by the use of subsoil irrigation (Kaca 1999). The design and operating principles of subsoil irrigation systems are described in many publications (Jurczuk and Mioduszewski 2006, Pływaczyk 2006, Mosiej et al. 2011).

This paper aims to analyze the variability of the surface and ground water level in peatland. The depth of ground water table occurred was studied with reference to the adopted terrain drainage standards. The studies were carried out in 2009/2010-2014/2015 for natural and regulated water outflows.

\section{MATERIAL AND METHODS}

Since October 1999 the Department of Environment Management and Geodesy Engineering at the University of Life Sciences in Lublin has carried out comprehensive studies of water resources in the Ochożanka river basin. The studies mainly involve: measurements of daily surface water levels in the gauges, measurements of ground water in piezometers, monthly outflow and geometric parameters of river. The measurements are performed both in the Ochożanka river and in drainage ditches.

This paper presents the results of hydrological measurements carried out in the period from $2009 / 2010$ to $2014 / 2015$, when the regulated outflow method was used for subsoil irrigation system. The tests were performed in the alder peatland Ambona, in an area of 181 ha, in hydrometric sections. The peatland was initially drained in 1933-1935, and the final network of subsoil irrigation ditches was constructed in the 1960s. The analyzed sections are supplied with water from the Ochożanka river, and they are drained by means of a $250 \mathrm{~m}$ away drainage ditch. Within the peatland there is a system of ditches with a spacing of $120 \mathrm{~m}$ and a depth of $100 \mathrm{~cm}$ perpendicular to the river (Fig. 1). The site is characterized by the occurrence of peat-muck soil MtIIcb with an average thickness horizon being $1.3 \mathrm{~m}$. The peatland Ambona is used as an extensive meadow and it forms part of the drying complex C.

Hydrological observations included:

- measurement of surface water levels in the river and ditches;

- measurement of the depth ground water table occurred in piezometers;

- maintenance processes (natural and regulated outflow).

Weather conditions in the catchment area were determined based on data provided by the meteorological station in Sosnowica. Digital data recorders were used for the purposes of hydrological and meteorological measurements.

Western Polesie, according to the division of Poland into climatic zones (Romer 1949), is located within the climatic area of the Great Valleys in the Chełm-Podlasie region (C 11). The region 


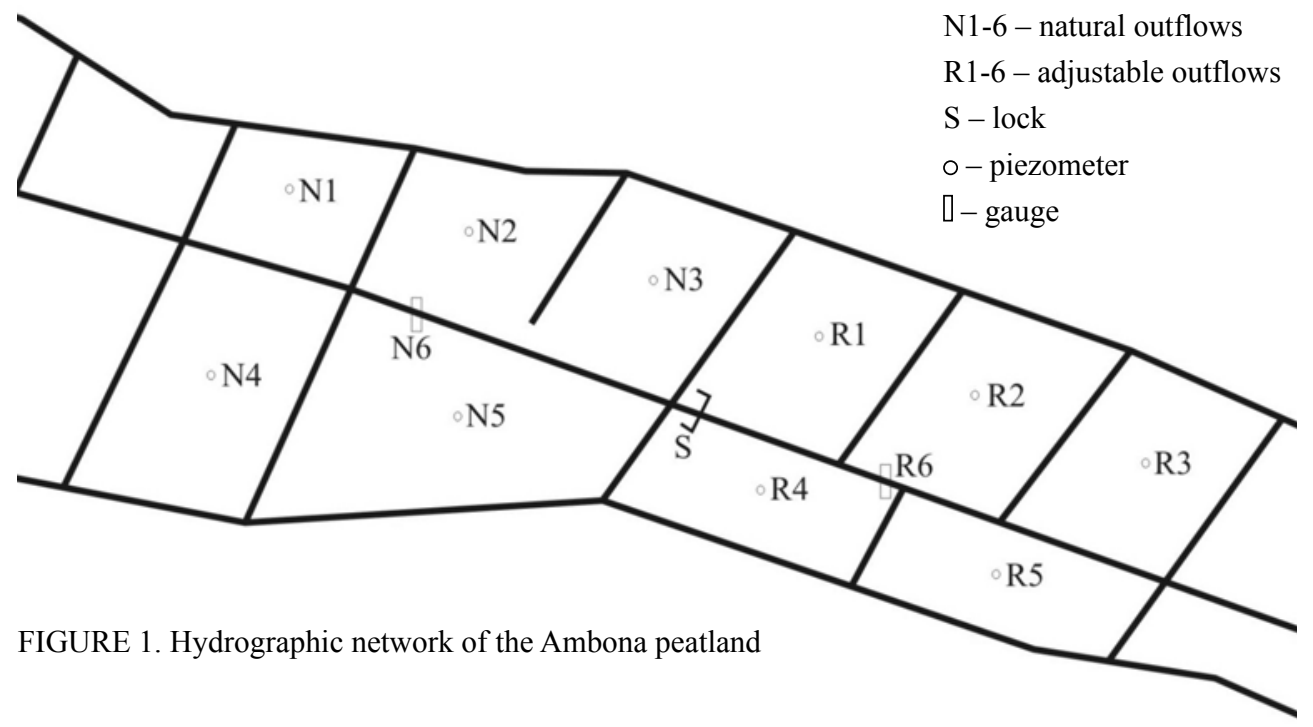

is characterized by high temperature amplitude reaching $23.5^{\circ} \mathrm{C}$ and the total precipitation of $560 \mathrm{~mm}$. The classification of agricultural regions (Gumiński 1950), the analyzed area is situated at the border of District IX - Eastern and District XIII - Chelm. The number of snow cover days is 80 and that of ground frost days 132. According to the classification of climatic regions (Okołowicz and Martyn 1979), this area is situated in the Mazovia region where summer starts early. Woś (1995) claims that the area of Polesie forms part of Region XIX - Polesie. According to the classification into climatic zones (Kaszewski 2008), this area is situated in Polesie Region which is characterized by very low climate variability.

\section{RESULTS}

The studies were carried out over six hydrological years in the Ambona peatland under variable precipitation conditions. It provided an opportunity for objective evaluation of the operation of the drainage system. The analysis of annual total precipitation suggests that in the analyzed period some years were very wet (2009/2010 and 2013/2014), some of them were wet $(2010 / 2011,2012 / 2013)$, one year was dry $(2014 / 2015)$ and one year was normal (2011/2012) (Kaczorowska 1962). The six-year average seasonal precipitation amounted to $593 \mathrm{~mm}$ (the Table), which was $66 \mathrm{~mm}$ higher than average precipitation recorded in 30 years (Grzywna et al. 2016). In the winter hydrological half-year the highest precipitation was recorded in 2013/2014 - $193 \mathrm{~mm}$, while the lowest in 2009/2010 - $134 \mathrm{~mm}$. Precipitation was considerably more varied in the summer half. It ranged from $262 \mathrm{~mm}$ in $2014 / 2015$ to $541 \mathrm{~mm}$ in $2009 / 10$ (51\% higher than the multi-year average). Precipitation distribution in a year was uneven and it ranged mean from $30 \mathrm{~mm}$ in December to $96 \mathrm{~mm}$ in May. In the studied period, the heaviest precipitation was recorded in July $2011-242 \mathrm{~mm}$, 
TABLE. Periodic precipitation totals

\begin{tabular}{|c|c|c|c|c|c|c|}
\hline \multirow{2}{*}{ Year } & \multicolumn{2}{|c|}{ XI-IV } & \multicolumn{2}{c|}{ V-X } & \multicolumn{2}{c|}{ XI-X } \\
\cline { 2 - 7 } & $\mathrm{mm}$ & classification & $\mathrm{mm}$ & classification & $\mathrm{mm}$ & classification \\
\hline $2009 / 2010$ & 134 & dry & 541 & extremely wet & 675 & very wet \\
\hline $2010 / 2011$ & 167 & normal & 486 & very wet & 653 & wet \\
\hline $2011 / 2012$ & 148 & dry & 373 & normal & 521 & normal \\
\hline $2012 / 2013$ & 189 & wet & 416 & wet & 605 & wet \\
\hline $2013 / 2014$ & 193 & wet & 490 & very wet & 683 & very wet \\
\hline $2014 / 2015$ & 205 & wet & 262 & very dry & 467 & dry \\
\hline Average & 177 & normal & 406 & wet & 593 & wet \\
\hline $1985-2014$ & 169 & normal & 358 & normal & 527 & normal \\
\hline
\end{tabular}

while the lowest amount was noted down in November 2011 and February $2015-2 \mathrm{~mm}$ (Fig. 2).

The normally positive water balance in the winter season and the negative one in the summer season indicate the need for very early storage of precipitation in the natural environment. Field studies under different water supply conditions revealed very poor water resources. Therefore, a regulated outflow irrigation system had to be used (Nyc and Pokładek 2001, Pokładek and Nyc 2007).
Thanks to all-year-round regulation of the outflows, the ground water level stopped decreasing. The operation of dams increased the stability of surface and ground water levels. Under regulated outflow conditions the variance in surface water levels remained below $22 \mathrm{~cm}$. The coefficient of variation of mean monthly water levels was $7 \%$. The level of surface water ranged from 55 to $77 \mathrm{~cm}$, given the depth river of $120 \mathrm{~cm}$ (Fig. 3). The highest average water levels were recorded in March, the lowest in

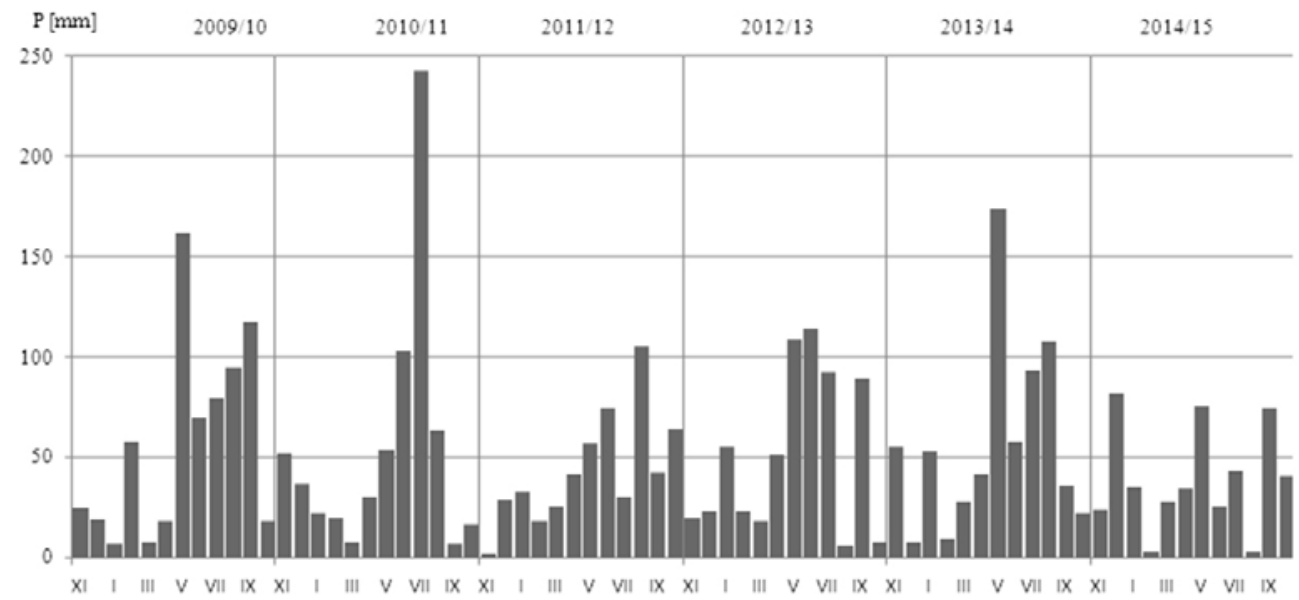

FIGURE 2. Monthly rainfall in 2009/2010 and 2014/2015 years 


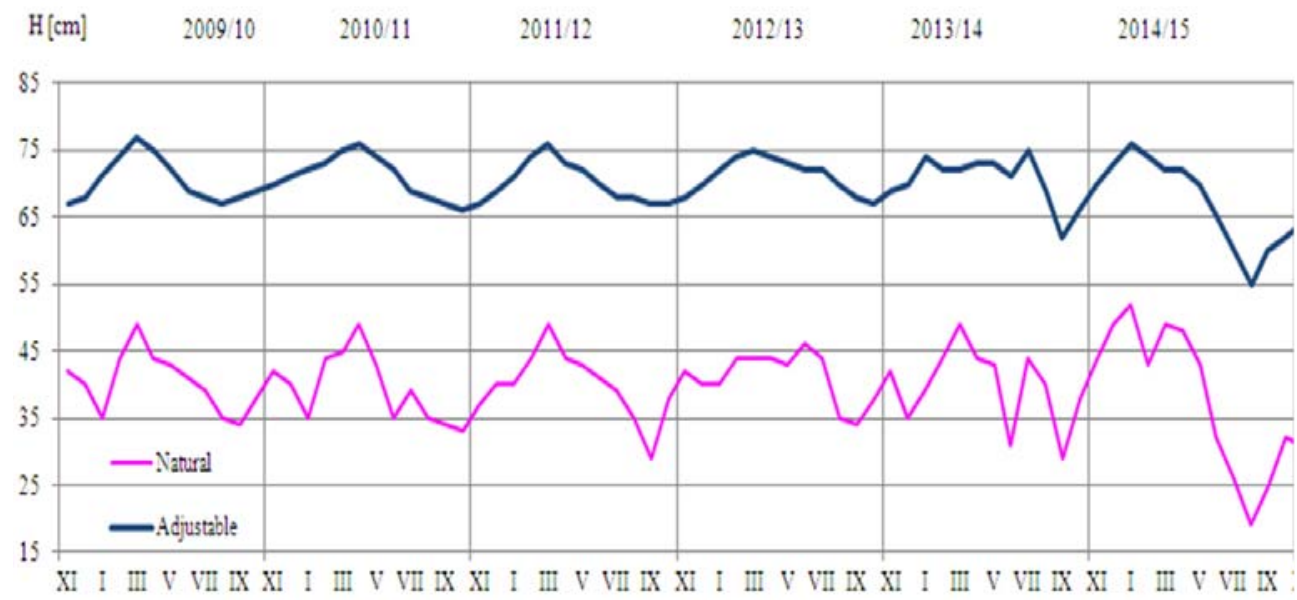

FIGURE 3. Monthly average of surface water levels $(\mathrm{H})$

August. The average water level of the multi-year was $68 \mathrm{~cm}$. For ground water levels the variance did not exceed $37 \mathrm{~cm}$. In the vegetation, the average meadow draining depth in irrigation system was $47 \mathrm{~cm}$ (Fig. 4). Ground water levels ranged from $28 \mathrm{~cm}$ at the March to $65 \mathrm{~cm}$ at the September. The analysis of groundwater table level in the middle of the meadow was performed considering the minimum $(30 \mathrm{~cm})$ and the maximum drainage standard value $(80 \mathrm{~cm})(\mathrm{Szu}-$ niewicz et al. 1991). Under natural outflow conditions the ground water level decreased excessively in 2012 and 2015 year. Thanks regulation of the outflows, the surface and ground water levels were successfully stabilized and the consequences of excessive dryness in the vegetation period could be prevented.

In the analogous period, at checkpoints located outside the dam impact zone, the

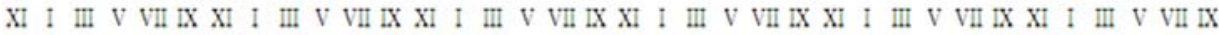

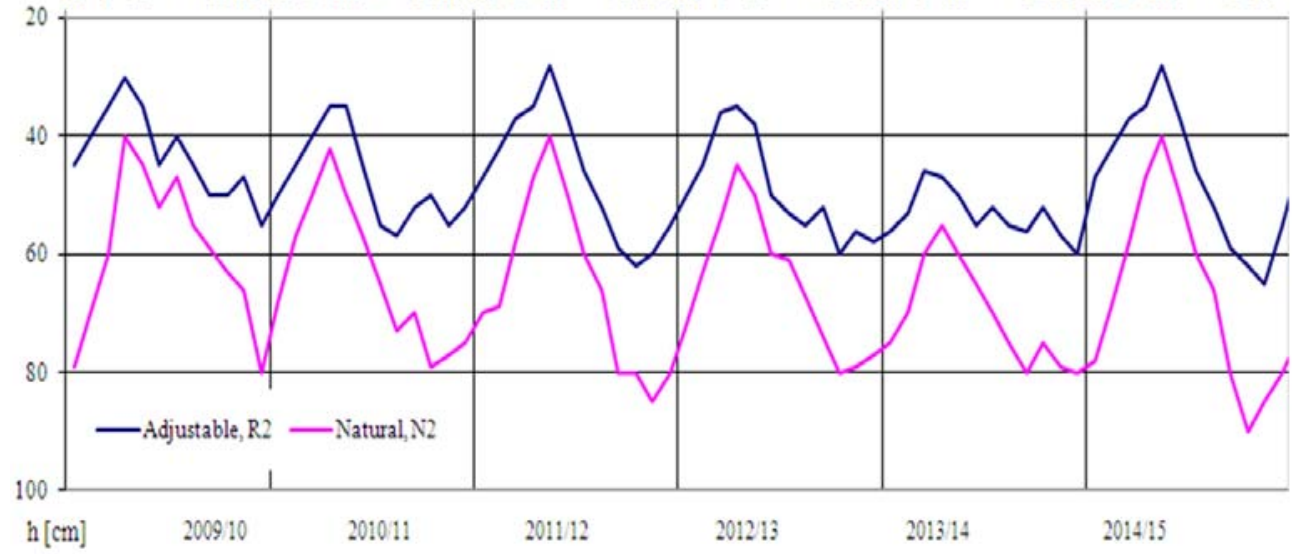

FIGURE 4. Monthly average of ground water depth (h) 
variance in surface water levels amounted to $31 \mathrm{~cm}$. The coefficient of variation of mean monthly water levels was $13 \%$. The level of water in the river ranged from 18 to $49 \mathrm{~cm}$, given $115 \mathrm{~cm}$ depth of the river (Fig. 3). The highest average water levels were recorded in March, the lowest in September. The average water level of the multi-year was $39 \mathrm{~cm}$ and $29 \mathrm{~cm}$ was lower than the regulated outflow. In the vegetation period the variance in ground water levels reached $67 \mathrm{~cm}$. Ground water levels ranged from $40 \mathrm{~cm}$ in March to $90 \mathrm{~cm}$ in August 2015 (Fig. 4). Under natural outflow conditions the ground water level decreased at the beginning of June. Similar in the irrigated area, the highest reduction in the level of water was recorded in 2015. In 2012 and 2015 soil drought occurred at drainage area. In the remaining years, despite high precipitation, the water level was also excessively reduced. Even in very dry vegetation periods in hydrological drought occurred.

A correlation analysis was carried out in order to determine the relationship between surface water levels in the river and ground water levels. Tests revealed a statistically significant relationship $(\alpha=0.05)$ between surface and ground water levels. The results indicate that the strongest relationship exists between the level of water in the river and the level of water in the centre of the meadow section $\left(r^{2}=0.51\right)$. The relationship between water levels to a strong hydraulic bond between surface waters and shallow ground waters that are characterized by a similar dynamics of changes mainly determined by the weather conditions.

The dynamics of ground water levels in the analyzed Ambona peatland was similar under natural and regulated outflow and it was mainly determined by the impact of weather conditions. The analysis of trends related to changes in surface and ground water levels in time consisted of testing hypothesis zero regression (Murat-Błażejewska et al. 2005). According to the analysis, was statistically significant of the surface water and ground water.

The lowest values of depth at which the ground water level was found were normally recorded in the centre of the meadow section. The lowest level of ground water was recorded near the drainage ditch (out of the dam). In dry year 2015 soil drought occurred at alls checkpoints. Analyzing the water table level in the cross-section, the lowest levels were observed in the river, which proves has a draining effect on the adjacent areas.

\section{CONCLUSIONS}

1. In small agricultural catchment areas with very limited water resources, outflow should be regulated to prevent hydrological and soil drought. As a result regulation of water in the river, the effects of maintaining large resources of stored water were very good. The average water level of the multi-year was $39 \mathrm{~cm}$ in natural outflow and $29 \mathrm{~cm}$ was lower than the regulated outflow.

2. In the irrigation system the average ground water level was $47 \mathrm{~cm}$. In the area of drainage system the average ground water level was $67 \mathrm{~cm}$. The dynamics of change in the water level under natural outflow was clearly higher. 
3. The effect of an irrigation system with regulated outflow on the levels of surface and ground water depends on correct agricultural management, related to the land use and function of the irrigation and drainage system and the value of precipitation.

\section{REFERENCES}

BAJKIEWICZ-GRABOWSKA E., MIKULSKI Z. 2006: Hydrologia ogólna [General Hydrology]. Wydawnictwo Naukowe PWN, Warszawa.

BRANDYK T. 2002: Stan retencji wodnej siedlisk hydrogenicznych i jego uwarunkowania [Water retention status of hydrogenic habitats and its determinations]. Wiad. Melior. Lak. 1, $18-21$.

BRANDYK T., GOTKIEWICZ J., ŁACHACZ A. 2008: Zasady racjonalnego wykorzystania torfowisk w rolnictwie [Formula of rational use of peatlands in agriculture]. ZPPNR 32 (1), $15-26$.

BYKOWSKI J., PRZYBYŁA Cz., RUTKOWSKI J. 2011: Stan urządzeń melioracyjnych oraz potrzeby ich konserwacji warunkiem optymalizacji gospodarowania wodą w rolnictwie na przykładzie Wielkopolski [The condition of irrigation system and the need to preserve it is a condition for water management in agriculture on the Wielkopolska region]. J. Res. Appl. Agricult. Eng. 56 (3), 45-51.

GRZYWNA A., CZARNECKI Z., WĘGOREK T. 2016: Ocena elementów składowych bilansu wodnego odwodnionego torfowiska [Assessment of components of the water balance of drained peatbog]. Rocz. Ochrona Środ. 18, 519-530.

GUMIŃSKI R. 1950: Ważniejsze elementy klimatu rolniczego Polski południowo-wschodniej [Important elements of the agricultural climate of south-eastern Poland]. Wiad. Stużby Hydrol. Meteorol. 3 (1), 57-113.

JURCZUK S., MIODUSZEWSKI W. 2006: Gospodarowanie wodą $\mathrm{w}$ dolinowych systemach melioracyjnych [Water management in drainage systems]. Woda - Środowisko - Obszary Wiejskie 18, 172-187.
KACA E. 1999: Modelowanie nawodnień podsiąkowych [The modeling of subsoil irrigation]. Bibl. Wiad. IMUZ 93.

KACZOROWSKA Z. 1962: Opady w Polsce w przekroju wieloletnim [Precipitation in Poland in the multi-year]. Prace Geograficzne 33.

KASZEWSKI M. 2008: Warunki klimatyczne Lubelszczyzny [Climatic conditions of the Lublin region]. Wydawnictwo UMCS, Lublin.

MICHALCZYK Z. 2000: Renaturyzacja obiektów przyrodniczych - aspekty ekologiczne i gospodarcze [Renovation of live science objects - ecological and economic aspects]. Wydawnictwo UMCS, Lublin.

MICHALCZYK Z., WILGAT T. 1999: Stosunki wodne Lubelszczyzny [Water conditions of the Lublin region]. Wydawnictwo UMCS, Lublin.

MIODUSZEWSKI W. 1999: Ochrona i kształtowanie zasobów wodnych w krajobrazie rolniczym [Protection and management of water resources in the agricultural landscape]. Wydawnictwo IMUZ, Falenty.

MOSIEJ J., PIERZGALSKI E., JEZNACH J. 2011: Współczesne uwarunkowania gospodarowania wodą $\mathrm{w}$ obszarach wiejskich [Contemporary conditions of water management in rural areas]. Post. Nauk Roln. 1, 25-36.

MURAT-BŁAŻEJEWSKA S., KANCLERZ J., SOJKA M. 2005: Zmienność stanów wód gruntowych i powierzchniowych $w$ zlewni rzeki Małej Wełny w latach hydrologicznych 2000-2004 [Variability of ground and surface water levels in the Mała Wełna river basin in hydrological years 2000-2004]. ZPPNR 506, 303-308.

NYC K., POKŁADEK R. 2001: Oddziaływanie systemu melioracyjnego $\mathrm{z}$ regulowanym odpływem na uwilgotnienie gleb i jakość wody [The impact of the drainage system with regulated outflow on soil moisture and water quality]. ZPPNR 475, 457-466.

OKOŁOWICZ W., MARTYN D. 1979: Regiony klimatyczne Polski [Polish climatic regions]. Atlas geograficzny Polski. Wydawnictwo PPWK, Warszawa.

OLESZCZUK R., CHRZANOWSKI S., BRANDYK T., GNATOWSKI T., SZATYŁOWICZ J. 2009: Ocena funkcjonowania systemu odwadniająco-nawadniającego dla zrównoważonego łąkowego wykorzystania gleby torfowo-murszowej [Evaluation of the functioning of the 
drainage and irrigation system for the sustainable meadow use of peat-muck soil]. Woda - Środowisko - Obszary Wiejskie 25, 77-86.

OLESZCZUK R., CHRZANOWSKI S., GNATOWSKI T. 2012: Analiza stosunków powietrzno-wodnych gleby torfowo-murszowej $\mathrm{w}$ zasięgu działania systemu nawodnień podsiąkowych [Analysis of air and water conditions of peat-muck soil within the subsoil irrigation system]. Woda - Środowisko - Obszary Wiejskie 37, 93-104.

PŁYWACZYK A. 2006: Systemy i technologie nawadniania [Irrigation systems and technologies]. [In:] S. Kaczmarek, L. Nowak (Eds). Nawadnianie roślin. PWRiL, Warszawa, 121$-156$.

POKŁADEK R., NYC K. 2007: Możliwości gospodarowania wodą $\mathrm{w}$ małych zlewniach rolniczych [The possibility of water management in small agricultural catchments]. ZPPNR 519, 259-268.

ROMER E. 1949: Regiony klimatyczne Polski [Polish climatic regions]. Prace Wroc. Tow. Nauk., ser. B 16, 26.

SZUNIEWICZ J., JAROS H., NAZARUK G. 1991: Gospodarka wodna gleb torfowych [Water management of peat soils]. Biblioteka Wiadomości IMUZ 77, 43-58.

WOŚ A. 1995: Zarys klimatu Polski [Climate Polish base]. Bogucki - Wydawnictwo Naukowe, Poznań.

ZIELIŃSKI J., SŁOTA H. 1996: Stan i wykorzystanie zasobów wód powierzchniowych Polski [Condition and use of surface water resources in Poland]. IMGW, Gospodarka Wodna i Ochrona Wód 20, 52.

Streszczenie: Wptyw regulowanego odptywu na wahania stanów wody powierzchniowej $i$ gruntowej. Celem artykułu jest analiza zmienności stanów wody powierzchniowej i wody gruntowej na torfowisku olesowym Ambona o powierzchni 181 ha (Polesie Zachodnie). W pracy przedstawiono analizę zmian warunków meteorologicznych (opady atmosferyczne). Kolejnym aspektem badań była dynamika wahań stanów wody powierzchniowej w rzece Ochożanka. Dokonano także odniesienia głębokości położenia zwierciadła wody gruntowej do ustalonych norm odwodnienia terenu. Badania były prowadzone w latach 2009/2010-2015/2016 w warunkach naturalnego i regulowanego odpływu wody. Badania prowadzono przez 6 lat hydrologicznych w warunkach zróżnicowanego zasilania opadem atmosferycznym. Stwarzało to możliwość obiektywnej oceny działania systemu melioracyjnego. $\mathrm{Z}$ analizy rocznych sum opadów wynika, że $\mathrm{w}$ analizowanym okresie występowały lata bardzo wilgotne (2009/2010 i 2013/2014), lata wilgotne $(2010 / 2011,2012 / 2013)$, rok normalny (2011/2012) oraz rok suchy (2014/2015). Przeciętne opady z 6 lat wynosiły $593 \mathrm{~mm}$ i były o $66 \mathrm{~mm}$ wyższe od średnich z 30-lecia. Rozkład opadów w ciągu roku był nierównomierny i wahał się od $30 \mathrm{~mm}$ w grudniu do $96 \mathrm{~mm}$ w maju. W wyniku całorocznego regulowania wody w cieku głównym uzyskiwano bardzo dobre efekty utrzymania dużych zasobów retencji wodnej. Średni stan wody przy naturalnym odpływie wynosił $39 \mathrm{~cm} \mathrm{w}$ okresie wieloletnim i był o $29 \mathrm{~cm}$ niższy niż przy regulowanym odpływie. Na obszarze z regulowanym odpływem średnia głębokość odwodnienia wynosiła $47 \mathrm{~cm}$. $\mathrm{Na}$ pozostałym terenie nieobjętym działaniem systemu nawadniającego głębokość odwodnienia wynosiła $67 \mathrm{~cm}$. Dynamika wahań poziomu zwierciadła wody gruntowej w przypadku naturalnego odpływu była wyraźnie większa. Skuteczność oddziaływania systemu melioracyjnego $\mathrm{z}$ regulowanym odpływem na poziomy wody powierzchniowej i wody gruntowej jest uzależniona od prawidłowej gospodarki rolnej, realizacji procesów eksploatacyjnych $\mathrm{w}$ zakresie obsługi i utrzymania systemu melioracyjnego oraz wysokości i rozkładu opadów.

\section{MS received November 2017}

\author{
Authors' address: \\ Antoni Grzywna \\ Katedra Inżynierii Kształtowania Środowiska \\ i Geodezji \\ Wydział Inżynierii Produkcji \\ Uniwersytet Przyrodniczy w Lublinie \\ ul. Leszczyńskiego 7, 20-069 Lublin \\ Poland \\ e-mail: antoni.grzywna@up.lublin.pl
}

